\title{
Acute abdomen in a term pregnancy due to isolated tubal torsion
}

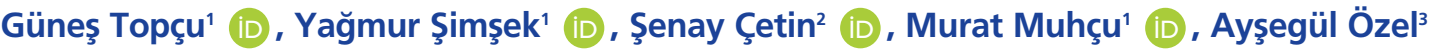 \\ ${ }^{\prime}$ Department of Obstetrics and Gynecology, Ümraniye Training and Research Hospital, Health Science University, Istanbul, Turkey \\ ${ }^{2}$ Department of Medical Pathology, Ümraniye Training and Research, Health Science University, Istanbul, Turkey \\ ${ }^{3}$ Division of Perinatology, Department of Obstetrics and Gynecology, Ümraniye Research and Training Hospital, Health Science University, Istanbul, Turkey
}

\begin{abstract}
Objective: Isolated tubal torsion in pregnancy is a rare condition we want to present this case.

Case: In our study, we present a 23 -year-old woman primigravida at 37 weeks of gestation with acute right lower abdominal pain. The clinical and Magnetic resonance imaging (MRI) findings led to diagnosis of acute appendicitis. Emergency exploratory laparotomy and cesarean section were performed. A twisted right Fallopian tube and Morgagni's cyst was noted and right salpingectomy was performed. Conclusion: Although isolated tubal torsion during pregnancy is very rare, it should be included in the differential diagnosis of acute abdomen in pregnancy. Early surgical intervention will decrease obstetric morbidity.
\end{abstract}

Keywords: Acute abdomen, pregnancy, isolated tubal torsion.

\section{Introduction}

Torsion of the Fallopian tubes is a rare cause of acute abdominal pain. The incidence of tubal torsion reported one in 1.5 million women and, only $12 \%$ of cases being identified during pregnancy. ${ }^{[1,2]}$ Etiology of tubal torsion may include hydrosalpinx, hematosalpinx, previous tubal surgery, cyst of Morgagni, adhesions, tubal abnormalities, medications which increase the tubal mobility (hormones etc.), and tubal trauma. It can also occur with healthy tubes. Other known etiological factors include varicose veins around tubes. ${ }^{[3,4]}$

It is hard to diagnose tubal torsion, because it is hard to differentiate it from other acute abdominal pain causes such as acute appendicitis, pelvic inflammatory dis-

\section{Özet: İzole tubal torsiyon nedeniyle miat gebelikte akut abdomen}

Amaç: Nadir bir durum olan gebelikte izole tubal torsiyon olgusunu sunmak.

Olgu: Çalışmamızda, sağ alt kadranda abdominal ağrısı olan, 23 yaşında primigravida ve 37 . gebelik haftasında olan bir olguyu sunduk. Klinik ve manyetik rezonans görüntüleme (MRG) bulguları, akut apandisit tanısına işaret etmekteydi. Acil eksploratif laparotomi ve sezaryen doğum gerçekleştirildi. Bükülmüşs să Fallop tüpü ve Morgagni kisti gözlemlendi ve sağ salpenjektomi yapıldı.

Sonuç: Gebelikte izole tubal torsiyon nadir olsa da, gebelikte akut abdomenin ayırıcı tanısına dahil edilmelidir. Erken cerrahi müdahale, obstetrik morbiditeyi azaltacaktır.

Anahtar sözcükler: Akut abdomen, gebelik, izole tubal torsiyon.

ease, ovarian torsion, renal colic, pyelonephritis, diverticulitis etc. Definitive diagnosis of tubal torsion is usually decided intraoperatively.

This case was operated with the initial diagnosis of acute appendicitis with preterm pregnancy; however, intraoperatively it was understood that right tubal torsion was the cause of the abdominal pain.

\section{Case Report}

A 23-year-old healthy primigravida, with medical history of gestational diabetes-using 10 units of insulin detemir (long-acting insulin) per day- presented with pruritis at a gestational age at 36 weeks and 2 day. Her

Correspondence: Ayşegül Özel, MD. Division of Perinatology, Department of Obstetrics and Gynecology, Ümraniye Research and Training Hospital, Health Science University, Istanbul, Turkey. e-mail: ozelaysegul@hotmail.com / Received: 1 Eylül 2020; Accepted: 12 Ekim 2020

Please cite this article as: Topçu G, Şimşek Y, Çetin S,, Muhçu M, Özel A. Acute abdomen in a term pregnancy due to isolated tubal torsion. Perinatal Journal 2020;28(3):217-220. doi:10.2399/prn.20.0283013

ORCID ID: G. Topçu 0000-0003-4784-6356; Y. Şimşek 0000-0001-8124-6245; Ş. Çetin 0000-0001-8520-5520 
vital signs, hemogram, urinary parameters were normal but, liver function parameters were increase (alanine aminotransferase levels increase to $296 \mathrm{U} / \mathrm{L}$, aspartate aminotransferase levels increase to $179 \mathrm{U} / \mathrm{L})$. The patient was admitted to inpatient service with a preliminary diagnosis of cholestasis and gestational diabetes. A single live fetus at 37 weeks of gestation with normal amniotic fluid and placenta were revealed by sonographic examination. The umbilical artery Doppler findings were normal. The nonstress test showed normal accelerations and variability of the fetal heart rate without uterine contractions. After high level of serum bile acids, treatment of ursodeoxycholic acid was started.

On the fifth day of her hospitalization, the patient complained of absence of appetite and abdominal pain in the right lower quadrant. Physical examination revealed abdominal enlargement compatible with pregnancy age and costovertebral angle sensitivity and no specific tenderness. Urinary ultrasound and complete urinalysis were planned; however, due to localized pain in the right lower quadrant, loss of appetite and leukocytosis in the new complete blood count with a raised C- reactive protein, the patient was consulted to the general surgery with a preliminary diagnosis of acute appendicitis. MRI was recommended and implemented. MRI results interpreted as acute appendicitis by the radiologist. The patient was informed and emergency exploratory laparotomy and cesarean section was planned. After the delivery of a healthy $3000 \mathrm{~g}, 9 / 10$ Apgar score baby via cesarean section, an observation was made: the right Fallopian tube had twisted four times around itself (Fig. 1), and the

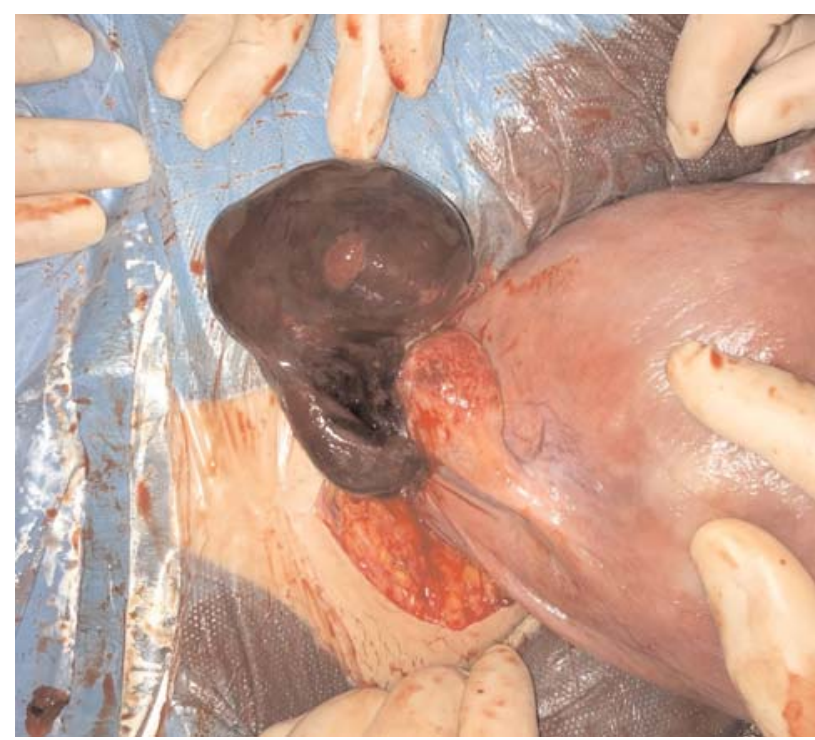

Fig. 1. The right Fallopian tube had twisted four times around itself.

distal tip of the tube was adherent to the back of the uterus with a necrosis measuring $6 \times 3 \mathrm{~cm}$ in size. We also noticed a $20 \mathrm{~mm}$ cyst of Morgagni which was located at the fimbriated ends. Salpingectomy was performed. Due to distal part of the appendix was edematous and inflamed, general surgeon invited and consulted intraoperatively. Appendectomy was performed. Tubal hemorrhage and necrosis were confirmed by histopathological examinations. However, the histopathology report did not indicate that part of the appendix showed primary inflammation (Figs. 2a and b).
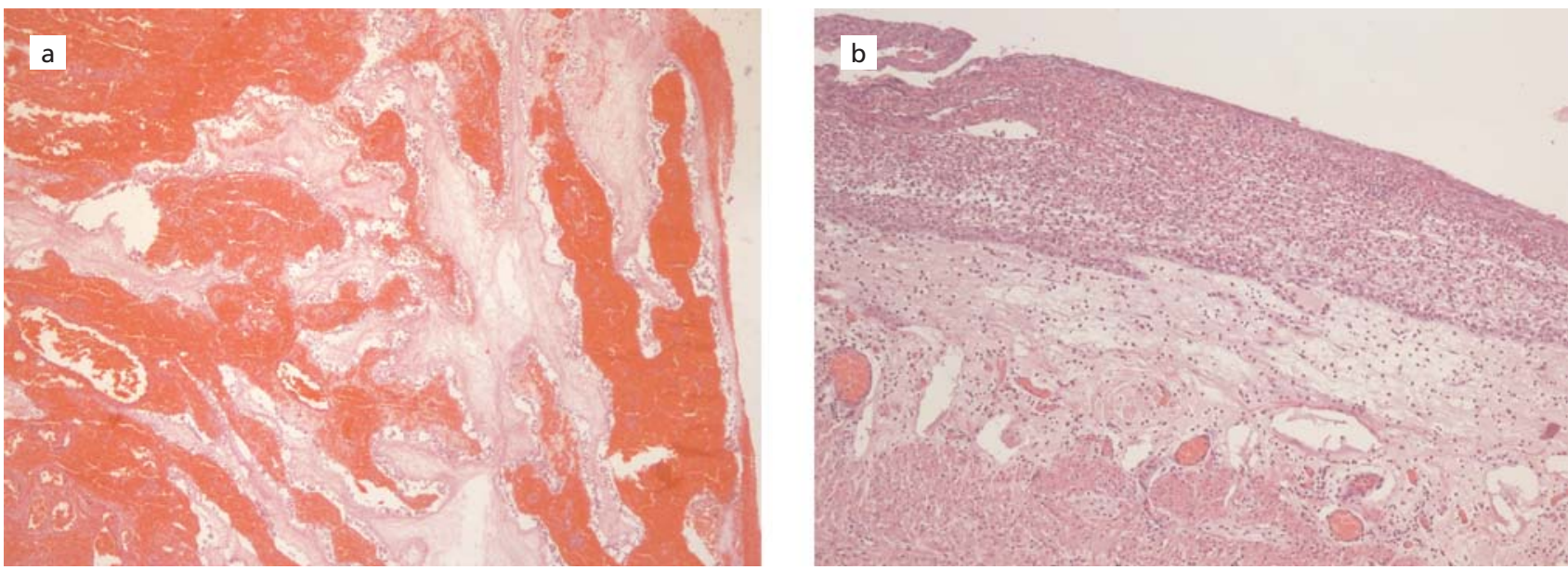

Fig. 2. (a) The histopathological image of right tubal hemorrhage and necrosis ( $H \& E \times 100)$. (b) The histopathological image of the appendix $(\mathrm{H} \& \mathrm{E} \times 100)$. Periappendicitis is seen as secondary tubal torsion associated peritoneal inflammation. 
Postoperative recovery was uneventful, insulin and ursodeoxycholic acid were stopped after the c- section. The blood sugar levels and liver function tests were normal.

\section{Discussion}

Tubal torsion is seen rarely during pregnancy. Approximately 31 isolated tubal torsion cases during pregnancy seem to have been reported from 1936 till today in English literatures. ${ }^{[5-8]}$

This case doesn't have any previously known etiological factors, but in the preoperative observation there was a cyst of Morgagni on the right side. Morgagni's cysts are Wolffian duct remnants located at the ends of the Fallopian tubes. These are usually asymptomatic. and rarely undergo torsion with Fallopian tube. ${ }^{[6]}$

The unspecific clinical findings make it difficult to identify an isolated tubal torsion preoperatively. Nausea, vomiting and lower abdominal pain are the most important symptoms of tubal torsion. The case in this report had abdominal pain in her right lower quadrant, loss of appetite and white blood cells were slightly elevated. Acute appendicitis, ovarian torsion, ruptured ovarian cyst, tubo-ovarian abscess, salpingitis, urolithiasis, degenerated leiomyoma and ablatio placenta can mimic the symptoms and findings of tubal torsion. ${ }^{[9]}$ Acute appendicitis is frequently confused with right tubal torsion as in this case. Tubal torsion occurs usually on the right side. Probable reason of tubal torsion occurs usually on the right side where small intestine and appendix can easily move but on the left side sigmoid colon is attached to the mesentery. As a second reason, it may be due to slow venous drainage on the right side, resulting in congestion. ${ }^{[10,11]}$

Although the imaging in tubal torsion cases are usually nonspecific, MRI is helpful in cases where the diagnosis remains unclear, especially in young or pregnant patients with undetermined sonographic findings. It is also the safe option because of great contrast of soft tissue and lack of radiation for pregnant women. One of the reasons why the present case was misdiagnosed is that we did not perform a preoperative ultrasonography for patient's pain in the right lower quadrant. Secondly, because of the emergency condition of the patient, we weren't able to examine MRI images. We recognized a cystic dilatation at the right adnexal side on the MRI images after surgical intervention (Fig. 3).

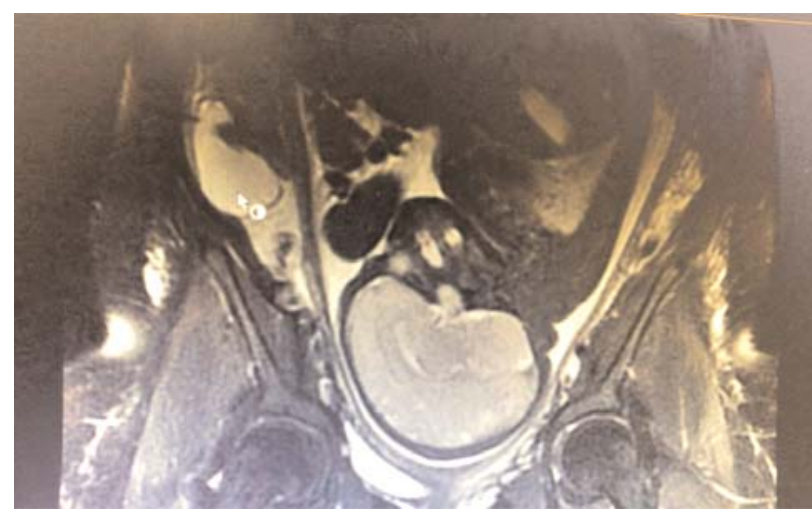

Fig. 3. Dilated and cystic structure on the right adnexal area (white arrow) was interpreted as twisted right tube after surgical intervention retrospectively.

The technical approach in surgical intervention is also an important issue in a pregnant woman. However, laparoscopic approach was found safety in a recent study by Walsh et al. ${ }^{[12]}$ which focused on appendectomies in pregnancy. We opted an open surgical approach due to the patient was at 37 weeks of gestation. We also preferred salpingectomy rather than detorsion as in most cases reported in the literature ${ }^{[2,7]}$ because of the Fallopian tube was edematous with hemorrhaged infarction and necrosis.

\section{Conclusion}

It is so difficult to establish a final diagnosis preoperatively in tubal torsion. Aggressive management including early surgical invention is indicated in such cases to prevent obstetric complications. Imaging techniques may be suggestive but not conclusive. Therefore, a pregnant patient with acute abdomen should first be evaluated with the clinical findings.

Conflicts of Interest: No conflicts declared

\section{References}

1. Antoniou N, Varras M, Akrivis C, Kitsiou E, Stefanaki S, Salamalekis E. Isolated torsion of the fallopian tube: a case report and review of the literature. Clin Exp Obstet Gynecol 2004;31:235-8. [PubMed]

2. Phupong V, Intharasakda P. Twisted fallopian tube in pregnancy: a case report. BMC Pregnancy Childbirth 2001;1:5. [PubMed] [CrossRef]

3. Comerci G, Colombo FM, Stefanetti M, Grazia G. Isolated fallopian tube torsion: a rare but important event for women of 
reproductive age. Fertil Steril 2008; 90: 1198.e23-5. [PubMed] [CrossRef]

4. Yen CF, Lin SL, Murk W, Wang CJ, Lee CL, Soong YK et al,. Risk analysis of torsion and malignancy for adnexal masses during pregnancy. Fertil Steril 2009;91:1895-902. [PubMed] [CrossRef]

5. Park, Seong Nam. Isolated tubal torsion in the third trimester of pregnancy managed with simultaneous salpingectomy and cesarean section. Yeungnam Univ J Med 2019;36:59-62. [PubMed] [CrossRef]

6. Ercan F, Bayram M, Balci O, Yildirim MA, Kucukkartallar T. Fallopian tube torsion due to Morgagni cyst in second trimester of pregnancy: a case report. Selcuk Med J 2019;35: 130-2. [CrossRef]

7. Origoni M, Cavoretto P, Conti E, Ferrari A. Isolated tubal torsion in pregnancy. Eur J Obstet Gynecol Reprod Biol 2009;46: 116-20. [PubMed] [CrossRef]
8. Ouassour S, Alami MH, Tazi Z, Filali AA, Bezad R. Isolated Fallopian tube torsion in pregnancy: an uncommon event. MOJ Clinical \& Medical Case Reports 2017;7:00192. [CrossRef]

9. Sun Y, Liu LL, D JM. Isolated tubal torsion in the third trimester of pregnancy: a case report and review of the literature. J Res Med Sci 2014;19:1106-9. [PubMed]

10. Erdemoğlu M, Kuyumcuoğlu U, Kale A. Pregnancy and adnexal torsion: analysis of 20 cases. Clin Exp Obstet Gynecol 2010; 37:224-5. [PubMed]

11. Varghese U, Fajardo A, Gomathinayagam T. Isolated fallopian tube torsion with pregnancy - a case report. Oman Med J 2009; 24:128-30. [PubMed] [CrossRef]

12 Walsh CA, Tang T, Walsh SR. Laparoscopic versus open appendicectomy in pregnancy: a systematic review. Int J Surg 2008;6:339-44. [PubMed] [CrossRef]

Bu makalenin kullanım izni Creative Commons Attribution-NoCommercial-NoDerivs 3.0 Unported (CC BY-NC-ND3.0) lisansı aracılığıyla bedelsiz sunulmaktadir. / This work is licensed under the Creative Commons Attribution-NonCommercial-NoDerivs 3.0 Unported (CC BY-NC-ND3.0) License. To view a copy of this license, visit http://creativecommons.org/licenses/by-nc-nd/3.0/ or send a letter to Creative Commons, PO Box 1866, Mountain View, CA 94042, USA. 